\title{
A Method for Abstracting Newspaper Articles by Using Surface Clues
}

\author{
Hideo Watanabe \\ IBM Research, Tokyo Research Laboratory \\ 1623-14, Shimotsuruma, Yamato-shi, Kanagawa-ken 242, JAPAN \\ watanabe@trl.ibm.co.jp
}

\begin{abstract}
This paper describes a system which automatically creates an abstract of a newspaper article by selecting important sentences of a given text. To determine the importance of a sentence, several superficial features are considered, and weights for features are determined by multiple-regression analysis of a hand processed corpus.
\end{abstract}

\section{Introduction}

The rapid expansion of the Internet enables us to easily access a lot of information sources in the world. The ability to browse information quickly is therefore a very important feature of an information retrieval and navigation system. Abstraction of a document is one useful tool for quick browsing of textual information.

Generally, an abstract can be considered to be a concise text giving an outline of the original text. Creating an abstract requires deep semantic processing with broad knowledge, and the strategy for generating an abstract depends on the type of target text. Abstracts created by humans tend to differ according to their creators' background knowledge and interests. Furthermore, as stated in [6], the same person is likely to create different abstracts of the same text at different times. Simulating this human process is clearly outside the area that can be dealt with by current computational linguistics. There are, however, some cases in which an abstract can be created by using surface clues to make conjectures as to which portions are the most important without using deep semantic processing.

The most practical way to create an abstract is thus to determine the most important portions by using surface clues. There are two lines of research based on this approach: one analyzes some aspects of a text's structure, such as the rhetorical structure [7], and selects some sentences according to this structure $[5,3]$; the other analyzes surface features for each sentence in a given text and selects the most important sentences according to some heuristics $[6,1,9]$. In methods of former type, the rhetorical structure is appropriate for a relatively small set of sentences such as a paragraph, but it does not give enough information to create an abstract for a large set of sentences. In methods of the latter type, the validity of the heuristics is uncertain when the target text is changed. Therefore, this paper proposes a method for selecting important sentences by using an equation based on surface features and their weights, and a method for determining these weights by multiple-regression analysis of abstracts created by humans. The target texts of this method are Japanese newspaper articles.

\section{Surface Features of a Sen- tence}

The proposed method is to create an abstract by determining important sentences according to features extracted from each sentence. For each sentence in a given Japanese newspaper article, the following features ${ }^{1}$ are analyzed:

- Important Keywords: An important keyword is defined as a keyword that appears in another sentence or in a title. The number of points for this feature is the total number of occurrences of important keywords.

- Tense:

The tense of a sentence is analyzed as past or present. This feature gives 1 point for present, and 0 for past.

\footnotetext{
1 Most of these features were proposed in the previous studies. Keywords were proposed in [6], sentence location was proposed in [1], sentence type was proposed in $[1,9]$, etc., and rhetorical relations were proposed in studies using rhetorical structures such as [3].
} 
- Type of a Sentence:

Sentence types are fact, conjecture, or insistence. This feature gives 0 points for fact, 1 for conjecture, and 2 for insistence.

- Rhetorical Relation:

The rhetorical relations to the preceding context is analyzed as example, adverse, parallel, comparison, or connection. This feature gives 1 point for reason, 2 for example, and 0 for others.

- Distance from the beginning of a text: In general, sentences located near the beginning of a text tend to be important. Therefore, sentences in the first paragraph are given 5 points for this feature, sentences in the next paragraph 4 , and so on.

- Distance from the end of a text:

Sentences located near the ending of a text also tend to be important. Therefore, sentences in the last paragraph are given 5 points for this feature, sentences in the previous paragraph 4, and so on.

The tense of a sentence is simply determined to be past if it has "ta" (an inflection for the past tense) in the last phrase. ${ }^{2}$ The reason why tense is used is that sentences stating about the current fact seem to be more important than ones about the past fact in the context of editorial articles.

The sentence type is determined by checking special expressions in the last phrase. ${ }^{3}$ For instance, if the final phrase contains "bekida" ("should") or "nakerebanaranai" ("must"), then its sentence type is insistence; if it contains "darou" ("probably ..."), then its type is conjecture; otherwise, its type is fact. Examples of special expressions used to determine sentence type are as follows:

- Conjecture: kamosirenai (may), kanenai (be capable of), souda (likely to), youda (likely to), darou (probably), etc.

- Insistence: tai (want to do), hosii (want someone to do), bekida (should), nakereba-naranai (must), taisetu-dearu (important), hituyouda (necessary), etc.

\footnotetext{
${ }^{2}$ In this method, past does not imply the past tense in a strict sense but rather the sentence is not in the present tense. In Japanese, "ta" implies the past tense, completion, and so on. Most cases are actual instances of the past tense.

${ }^{3}$ It is sufficient to check in the last phrase for Japanese sentences, because a predicative phrase is always located at the end of a Japanese sentence. Therefore, a nother strategy is needed for languages in which a predicative phrase nuay be located in the tniddle of a sentence.
}

The rhetorical relation is determined by checking special expressions both in the first phrase and in the last phrase of a sentence. For instance, if "sitakarada" 4 is found in the last phrase, then the rhetorical relation is reason, and if the conjunction "sikasi" ("but") is found, then the rhetorical relation is adverse. ${ }^{5}$ Examples of special expressions used to determine rhetorical relations are listed below:

- Example: tatoeba (for instance), nado (etc.), etc.

- Adverse: sikasi (but), tokoroga (however), etc.

- Comparison: koreni-taisi (while), etc.

- Parallel: mata (further), sarani (in addition), etc.

- Reason: karada (because), tameda (because), etc.

\section{Process of Creating an Ab- stract}

The basic method for creating an abstract in most previous studies has been to analyze the sentences of a text in terms of some surface features, and a heuristic to determine the most important sentences on the basis of these features.

The method proposed in this paper formalizes the above approach so that the importance of each sentence is calculated as the sum of feature points multiplied by their feature weights. The most important sentences are then extracted as an abstract. The importance $S$ of a sentence is calculated as follows:

$$
S=a+\sum_{i=1}^{n} W_{i} * P_{i}
$$

where $a$ is a constant, $P_{i}$ is the number of points assigned to the $i$-th feature, which is normalized to be between 0 and 1 , and $W_{i}$ is the weight assigned to the $i$-th feature.

The steps in creating an abstract are as follows:

1. For each sentence, calculate the importance.

2. Select the sentence that has the highest importance value among the unselected sentences.

3. If the selected sentence $s_{1}$ has another sentence $s_{2}$ in the previous context that is related to $s_{1}$ by any rhetorical structure, then $s_{2}$ is also selected and marked.

\footnotetext{
"In English, this expression corresponds to "because" in the first phrase.

${ }^{3}$ These checking of sentence types and rhetorical relations are based on [10].
} 
4. If the ratio of the number of selected sentences to the number of sentences in the text exceeds the specified one, then terminate this process; otherwise, goto 2 .

These steps select sentences on the basis of their importance value, but they also respect the rhetorical structure to some extent (step 3 ), because if the rhetorical structure is totally ignored, the output text will be awkward to read.

\section{A Method for Determining the Weights of Features}

Most previous systems can be considered to determine the weights of features according to human intuition. On the other hand, this paper proposes a method for determining the wieghts of features by multipleregression analysis of correct examples, which are abstracts created by testers. A tester selects important sentences that should be included in an abstract. The importance value of a sentence is defined as the number of supporters (testers who selected it as an important one) divided by the total number of testers. Let this importance value be $S$; we then get the following equation for each sentence:

$$
S=a+\sum_{i=1}^{n} W_{i} * P_{i}
$$

where, $a$ is a constant, $P_{i}$ is the number of points assigned to the $i$-th feature which is normalized to be between 0 to 1 , and $W_{i}$ is the weight assigned to the $i$-th feature.

In this equation, $W_{i}$ is the only variable. Therefore, the feature weight $W_{i}$ is calculated by multipleregression analysis.

\section{Experiment}

We conducted an experiment to check the validity of the proposed method.

The testers were divided into two groups, $A$ and B, each consisting 10 people. Those in group $A$ selected important sentences (about $1 / 3$ of the article) in 5 editorials and 3 general articles from the Nikkei Newspaper. Those in group B selected important sentences (about $1 / 3$ of the article) in 3 editorials and 3 general articles, which were different from those used for group A. One of the editorials and one of the general articles

\begin{tabular}{|l|r|r|r|r|}
\hline \multirow{2}{*}{ Feature } & \multicolumn{2}{|c|}{$\begin{array}{c}\text { General } \\
\text { Article }\end{array}$} & \multicolumn{2}{c|}{$\begin{array}{c}\text { Editorial } \\
\text { Article }\end{array}$} \\
\cline { 2 - 5 } & $\begin{array}{r}\text { Weight } \\
\text { Set 1 }\end{array}$ & $\begin{array}{c}\text { Weight } \\
\text { Set 2 }\end{array}$ & $\begin{array}{r}\text { Weight } \\
\text { Set 1 }\end{array}$ & $\begin{array}{c}\text { Weight } \\
\text { Set 2 }\end{array}$ \\
\hline Constant & 0.0 & 0.183 & 0.0 & 0.039 \\
Keyword & 1.0 & 0.216 & 1.0 & 0.151 \\
Tense & 0.3 & -0.180 & 0.3 & 0.046 \\
Type & 0.3 & -0.331 & 1.0 & 0.089 \\
Relation & -1.0 & 0.127 & -1.0 & -0.279 \\
Location & 1.0 & 0.437 & 1.0 & 0.242 \\
(Beginning) & & & & \\
Location & 1.0 & -0.015 & 1.0 & 0.214 \\
(Ending) & & & & \\
\hline
\end{tabular}

Table 1: Weight Set of Features (General and Editorial Articles)

used for group $B$ are shown in Figures 1 (a) and 2 (a), respectively. In each of these figures, the first number is a sentence number, the second number is the number of supporters in group B, and the last part is a rough English translation. ${ }^{6}$

Table 1 shows two weight sets; weight set 1 was created by the author in such a way that sentences located near the beginning and end are regarded as important, sentence importance is not proportional to points for rhetorical relation, and the importance of insistencetype sentences is higher in editorials than in general articles. ${ }^{7}$ Weight set 2 , on the other hand, was calculated from the results obtained from group A by the method described in the previous section. Weight set 2 for general articles implies that sentences near the beginning are more important than ones near the end, and insistence-type sentences are less important, and so on. On the other hand, weight set 2 for editorials implies that sentences both near the beginning and near the end are important, and that insistence-type sentences are important. ${ }^{8}$

To check the validity of these weight sets, we compared the abstracts created by the system, using weight set 1 and 2, from the articles supplied to group B, with

\footnotetext{
"This translation was made by the author, and is not authorized by Nikkei Newspaper K.K.

${ }^{7}$ This weight set 1 corresponds to the way used in previous studies, where weights are determined according to human intuition.

${ }^{8}$ The weight set calculated in this method can be used as basic material for creating a practical system, because it is difficult to ask enough people to do this experiment to ensure that the result is statistically meaningful. However, the general tendency can be extracted, and the weight set is determined on the basis of this experiment.
} 
the abstracts created by group B. For the general article in Figure 1 (a), the three most important sentences (roughly $1 / 3$ of the article) determined by using the weight sets 1 and 2 are listed in Figures 1 (b) and (c), respectively. In this case, the three most important sentences selected by group $B$ were 0,2 , and 3 . Likewise, for the editorial in Figure 2 (a), the eight most important sentences (roughly $1 / 3$ of the article) determined by using weight sets 1 and 2 are listed in ligures 2 (b) and (c), respectively. In this case, the eight most important sentences selected by group $B$ are $0,2,3,12$, $15,20,21,22$. Here, we introduce the following metric of estrangement to check which abstract is most similar to the result of group B:

Estrangement $=\sum_{s_{i}}$ (the number of supporters of a sentence $\left.s_{i}\right)-\sum_{s_{j}}$ (the number of supporters of a sentence $s_{j}$ )

where $s_{i}$ is a sentence that is included in an abstract by group $\mathrm{B}$ but not in an abstract created by the system, and $s_{j}$ is a sentence that is not included in an abstract by group $B$ but is included in an abstract created by the system.

The estrangements of the articles in Figures 1 and 2 are as follows: From this result, the weight set 2 calcu-

\begin{tabular}{|c|c|c|}
\hline Fig. & Weight Set 1 & Weight Set 2 \\
\hline 1 & 14 & 6 \\
2 & 13 & 12 \\
\hline
\end{tabular}

lated by multiple-regression analysis is more similar to the human selection than the weight set 1 created according to the author's intuition. For the other general articles used with group $B$, the estrangement values of weight set 2 are also better than those of weight set 1. In the other editorials, the estrangement values are comparable. This implies that the weight set 1 is not such a bad estimate for editorials.

\section{Discussion}

So far, most systems for creating an abstract of a text has been selected important sentences by some heuristics on the basis of surface features. However, most of these heuristics were derived from human intuition, and the validity of them are uncertain if the target text is changed. As mentioned in the introduction, the strategy of an abstraction should be changed according to the given text. Therefore, it is needed to adjust these heuristics for the given text. This paper proposed a method for this adjustment; that is, a method for determining weights of surface features by multiple-regression analysis of abstracts created by human. By using this method, a system can have an ability to be applied to a variety of texts.

\section{Conclusion}

'This paper has proposed a method for creating an abstract by using surface features and their weights to select important sentences, and a method for determining these feature weights by multiple-regression analysis of abstracts created by humans. By using the proposed method to calculate feature weight, this system can be applied to other types of texts, and gives results more similar to those of a human process than a set of weights based on human intuition.

This abstract creation system is currently used in an information navigation assistance system [8] as a tool for quickly viewing the contents of newspaper articles.

\section{References}

[1] Edmundson, II, P'., "New Methods in Automatic Extracting, "Journal of the Association for Computing Machinery, Vol. 16, No. 2, pp. 264-285, April 1969.

[2] Kita, S., "A System for Summarization of an Explanatory Text" (in Japanese), Report 63-6 of NLWG of Information l'rocessing Society of Japan (IPSJ), 1987.

[3] Ono, K., Sumita, K., and Mike, S., "Abstract Generation based on Rhetorical Structure Lxtraction," Proc. of Coling'94, Vol.1, pp. 344-348, 1994.

(4) Tamura, ' $\Gamma$, and 'Tamura, $N$., "A Summary Generation based on The Form of Text" (in Japanese), Report 92-1 of NIWG of II'SJ, 1992.

[5] Schank, R. and Abelson, A., "Script Plans Goals and Understanding," Lawrence Frlbaum Associates, Millside, New Jersey, 1977.

[6] Luhn, H. P., "Ihe Automatic Creation of Literature $A b$ stracts," II3M Journal of Research and Development, Vol. 2, No. 2, PP. 159-165, 1958.

[7] Mann, W. C., "Rhetorical Structure Theory: Description and Construction of T'ext Structure," In G. Kempen, editor, Natural Language Generation, pp. 279-300, Martinus Nihjhoff Publishers, 1987.

[8] Morohashi, M., Takeda, K., and et. al., "Information Outlining - Filling the Gap between Visualization and Navigation in Digital Libraries," I'roc. of Int. Symposium on Digital Libraries 1995, pp. 151-158, 1995 .

[9] Yamamoto, K., Masuyama, S., and Naitou, S., "GREEN: An Experimental System Generating Summary of Japanese Editorials by Combining Multiple Discourse Characteristics" (in Japanese), Report 99-3 of ÑIWG of IPSJ, 1994. 
[10] Watanabe, H., Tsujii, J., and Nagao, M., "A Method for Analyzing Text Structure by Čsing Surface Clues of Sentence " (in Japanese), Proc. of 32nd Convention of IPSJ, pp.1633$1634,1986$.

Title: 最新鋭MPU搭载パソコン、I BM、来夏発売一低価格・高速 処理を実現。(IBM to release PC equipped with the latest MPU, featuring low cost and fast processing)

0 (10)【ニューヨーク10日二松本元裕】米 I BMは十日、最新鋭マイ クロプロセッサー(MPU、超小型演算処理装道)「パワーP C」を搭 载したパソコンを来年夏に発売することを明らかにした。(IBM Corporation announced on the 10th of this month that a personal computer equipped with the latest "PowerPC" microprocessor will be released next summer.)

1 (3)まずノート型を発売、続いてデスクトッブ型二機種を投入する。 (First, a notebook PC will go on sale; this will be followed by two types of desktop PC.)

2 (5)低価格で処理速度の高いパワーP Cは、I BM再生のカギを握る と言われるコンピェーターの心茼部品。(The "PowerPC" is used as a central part of a computer. It is cheap and has high processing power, and is said to be a key to IBM's recovery.)

3 (9) 同扗がパワーPC搭載パソコンの商品計画を明らかにしたこと で、他の日米欧のパソコン各杜も対抗策を迫られることになりそう た。 (Since IBM announced its plan to sell personal computers equipped PowerPCs, other PC makers in the world are likely to take countermeasures.)

4 (3) 発売する三機種はC D-ROM、マイク、ステレオオーディ 才、音声認識機能を標準装借して、マルチメデイア機能を高める計画。 (The above three types of $\mathrm{PC}$ will provide additional multimedia functions by including CD-ROM, microphone, stereo audio, and roice recognition functions as standard features.)

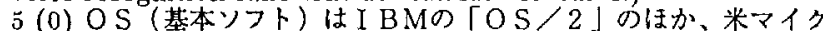
ロソフの「ウィンドウズNT」サン・マイタロシステムズの「タ ラリス」などにも対応できるようにする。(IBM's OS/2, Microsoft's Windows NT, and Sun Microsystems' Solaris will be installed as operating systems.)

$6(0)$ パワーPCはI BM、アップルコンピュー夕、モトローラの三 社が共同開発したR I S C (維小命令七ットコンビェーター) 型MP $U_{0}$ ("PowerPC" is a RISC-type MPU developed by IBM, Apple, and Motorola.)

7 (2) パソコン用M P U市場で事実上の標整機種になっているインテル 製MP Uに対抗するための滴品で、低価格・高速处理が特徴だ。 (It is intended to compete with Intel CPUs, which are de-facto standards in the PC microprocessor market. Its main advantages are low price and fast processing.)

8 （1）パソコン業界二位のアップルがパワーP C塔载パソコンを来年 発壳する計画を発表。(The second largest PC maker, Apple, has announced a plan to release a "PowerPC"-based PC next year.) 9 (0) 同一位の I BMはパワーP C内盛のワークステーションをすて に発売しているが、パソコンについては憋品計画を明らかにしてい なかった。 (The largest PC maker, IBM, has already released a PowerPC-based workstation, but has not announced any corresponding plan for PCs.)

10 (1) I BMはパワーPCを外販するだけでなく、搭載パソコンの技 術估栚を外部に有䖵で公開、パワーPC搭载パソコンのファミリー作 りを進好計画。(IBM plans to sell PowerPCs to other vendors license the technology, and create a family of PowerPC-based PC.)

11 (3) アップルなどと合わせたパワーPC搭载パソコン全体で、世 界の市場に占めるシエアを最低二％％程度までもっていきたい考之。

(Together with Apple and others, IBM aims to gain at least a $20 \%$ share in the PC market for PowerPC-based PC.)

\section{(a) Original Article}

2 (5) 低価格で処理速度の高いパワーP Cは、I BM再生のカギを握 ると言われるコンピローターの心䑏部品。
10 (1) I BMはパワーP Cを外販するだけでなく、搭载パソコンの 技術仕様を外部に有供で公開、パワーP C搭载パソコンのフォミリー 作りを進める部画。

11 (3) アップルなどと合わせたパワーP C搭载パソコン全体で、世 界の市場に占めるシェア最最低二○\%程度までもっていきたい考え。

(b) Abstract by Weight Set 1

0 (10)【二エーヨーク10日二松本元裕】米 I BMは十日、最新鋭 マイタロプロセッサー（MPU、超小型演算処理装置)「パウーPC を搭載したパソコンを来年夏に発売することを明らかにした。 1 (3)まずノート型を発売、続いてデスクトップ型二機種を投入す る。

2 (5) 低価格で処理速度の高いパワーP Cは、I BM再生のカギを握 ると言われるコンピューターの心䁍部品。

\section{(c) Abstract by Weight Set 2}

Fig. 1: An Example of Abstract of General Article (Nikkei Newspaper, 1 Nov. 1993)

Title:「経済難民」稀め出しを決めたドイツ（社説）(Germany determined to shut out economic refugees.)

0 (10)ドイツの議会が基本法（憲法）を改正して、負困なと释済的理由 による外国人の移住を認めないことにした。(The German Diet has revised the constitution to prohibit immigration for economic reasons such as poverty.)

1 (3)受け入れは政治亡命に限り、いわ稀済蜼民を楴め出そうとい $う わ け t た 。$ (The aim of this move is to shut out economic refugees and accept only political refugees.)

2 (8) 理想主䕏の後退は残念だが、重い財政顛担、ドイッ社会の現 状などから見て、やむを得ない措置といえよう。(This retreat from idealism is disappointing, but in view of the current situation of Germany, it is an inevitable measure.)

3 (6) 七月から実施する规制措置は、「迫害のない国」（ルーマニア、ブ ルガリア、ハンガリーなど)からの亡命は例外を除いて受け入れず、 政治亡命老嫼めている[安全な第三国](西欧とポーランド、チェコ の計十八力国）を経由してきた難民は経由国に送り返す、というも O $\$^{\circ}$ (The restriction, which will come into effect in July, will prohibit refugees from "countries without persecution" (e.g. Romania, Bulgaria, and Hungary) from being granted entry except in special cases, and will repatriate political refugees through "safe countries" (e.g. western European countries, Poland, and Czechoslovakia) which permit political refugees.)

4 (1) 東欧革命などで民主義体制に転換した国々から政治亡命者が 出るはずがないという論理である。(The logic behind this is that there cannot be political refugees from countries that have been converted into democratic nations by the East European Revolution, and so on.)

5（2）第二次大戦後の一九四九年に制定された基本法の第一六条二項は 「政治的に迫害されたた者は庇鿁（ひご）を受ける梅利がある」と規定し、 亡命者に寛大だった。(Clause 2, Article 16 of the Basic Law established after WWII, in 1949, was generous to refugees stating that people persecuted politically had a right to be protected.) $6(0) こ$ 机は、十千時代の排外主棌が他民族作危害を加え、ドイツか らも多くの移民を生み出したことに対する反省に基づいている。 (It was based on the reflection that anti-foreign policies in the ' $\mathrm{Nazi}$ ' era had hurt foreign nations and produced many refugees from Germany.)

$7(0)$ 杜会主義国家の存在を强〈意諳して、この理想主義的な条項をつ くったともいう。 (It is also said that this clause was created out of strong consideration for socialist states.)

8 (2) だが、ドイツが統一され、東西冷戦が終わると、状況は一変し たo (However, Germany's situation has been totally changed by the unification of Germany and the end of the cold war.)

9 (1) 昨年一年閒で西欧主要国に流入した難民仙申觖べースで七十 万人に達し、規制が楥いドイツは四十四丹人と全体の六割を超えた。 (The number of refugee applicants arriving in major Western European countries last year reached 700,000 , among whom the 
number arriving in Germany, which has loose restrictions, was 440,000 , over $60 \%$ of the total for Europe.)

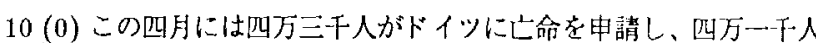

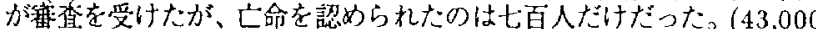
people applied to Germany for refugee status this April; of these, 410,000 were interviewed but only 700 were accepted.)

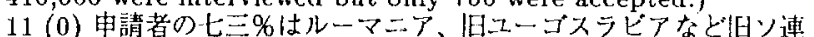
東欧からの人々で占められる。(73\% of applicants are from Easter Europe or ex-soviet-bloc countries such as Romania, and former Yugoslavia.

$12(0)$ 一方で、不法入国 後を秝たない。(At the same time, there is a constant flow of entrants.)

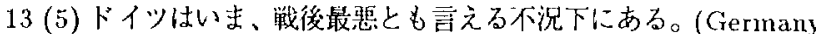
is now said to be suffering the worst recession since WVII.) $14(0)$ 旧西ドイッ地域の失業轧は四月で七・一\%だが、释济再建が羊 れている旧東ドイッ地域は一四・七\%と䯩い。(The unemployment rate in April was $7.1 \%$ in former West Germany, and $14.7 \%$ in former East Germany.)

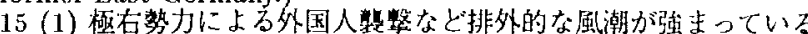
のは、大草に流入してきた外国人が自分たちの職を寉うのでは、と いう不安があるからだ。(There is a growing anti-foreign tendency manifested in attacks on foreigners by ultra-rightist groups, resulting from anxiety that masses of immigrants will take native people's jobs.)

16（4）難民はいっだん、収谷旅設に入り、籍査が䅂わるまでそこて 春ら子が、その費用貟担が各州や市朾村に重くのしかかっている。 (Refugees enter government-provided accommodation and live there until their inverviews are completed, with their expenses borne by states and cities.)

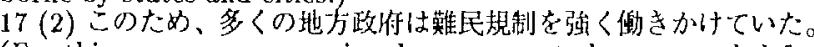
(For this reason, many regional governments have appealed for the numbers of refugees to be restricted.)

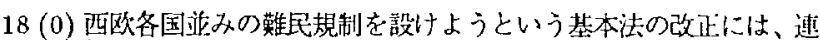
立与党各党のほか、野党・榇会民主党の議貝の多くも替成した。 Most Diet members in coalition government parties and social liberalist party approved the revision of the Basic $I_{4}$ aw, which imposes restrictions on refugees similar to those of other major Western European countries.)

19 (3) 戦後好理、冷戦の後始末という意味あいもあり、ドイツにとっ てひとつの時代が䅂わったという印象索受ける。(The move is also intended to be a post-war process and the settlement after the Cold War, and gives the impression of the end of an era in Germany.)

20 (0) フランスなど他の西欧各国も程洞難民の规制強化に踏み切 っている(Other major Western European countries such as France have also decided to impose more restrictions on economic refugees.)

21 (4) 督しい国の人々が量かな国へ行こうとするのは自然の战り行き たが、大量の移動は混乱と磨擦を生を。(It is natural for poor people to try to go to rich countries, but the movement of many people produces confusion and friction.)

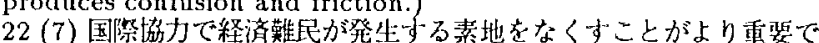
あり、西欧各国が一定の制限を設けるのbやむを得まい。(It is important to alleviate the conditions that produce economic refugees through world-wide cooperation, and it may be inevitable for European countries to impose some level of restricts.)

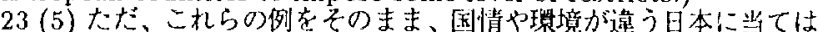

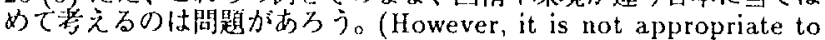
apply these examples to Japan, because Japan's circumstances are different from those in Europe.)

\section{(a) Original Article}

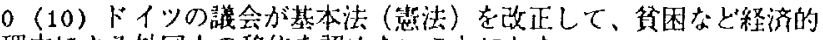
理时による外国人の移住を認めないことにした。

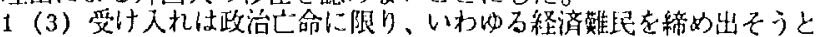
いうわ什た

2 (8) 理想主義の後退は残念だが、重い敗政摃担、ドイッ扑会の現状 などから見て、やむを得ない措界といるよう。

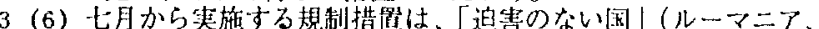

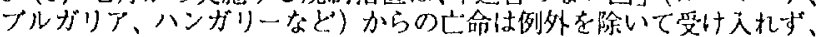

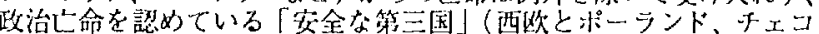

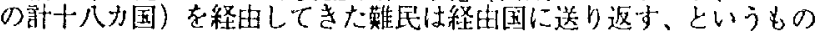

18 (0) 酉欧各国並みの難民规制を設けようという基本法の改正には、 連立与党各党のほか、野党・社会民主党の議買の多く替成した。

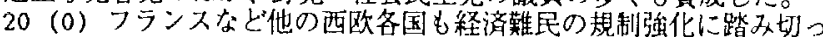
ている。

21 （4）督しい国の人々が豊かな国入行こうとするのは自然の成り行 きたか、大量の移動は混乱之摩徖を生む。

22 (7) 国際協少で経済難民が発生する素地をなくすことがより重要

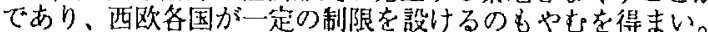

(b) Abstract by Weight Set 1

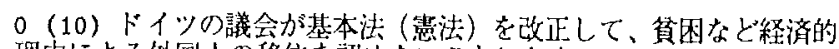
理由による外慖人の移住老認めないことにした。

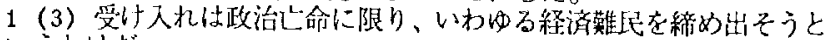
いう柿だ。

2 (8) 理想主義の後甚は残念だが、重い財政真担、トイッ社会の現状 なとから見て、やむ在得ない措䐈とい方よう。

3（6）七月から英施する規制措圈は、「迫害のない国」（ルーマニア、

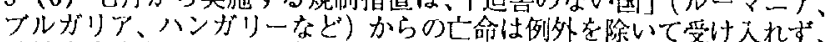

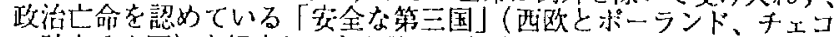

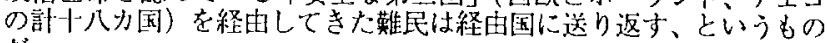
$+0$

4（1）柬欧草命などで㞎主主義体制に転換した国々から政治亡命者が 出るはずがないという論理である。

$20(0)$ フランスなど他の西欧各国も経済難民の規制強化に踏み切つ ている。

21 (4) 筫しい国の人々が曹かな国へ行こうとするのは自然の成り行 きだが、大量の移動は混乱と摩擦を生を。

22 (7) 国際協力で絟済難民が発作する素地をなくすことがより重琶 であり、西欧备国がー定の制限を設けるのもやむを得まい。

(a) Abstract by Weight Set 2

Fig. 2: An Example of Abstract of Editorial (Nikkei Newspaper, 1 Jun. 1993) 